\title{
GmCOI1, a Soybean F-Box Protein Gene, Shows Ability to Mediate Jasmonate-Regulated Plant Defense and Fertility in Arabidopsis
}

\author{
Zhilong Wang, ${ }^{1,2}$ Liangying Dai, ${ }^{1,3}$ Zide Jiang, ${ }^{1,4}$ Wen Peng, ${ }^{1}$ Lianhui Zhang, ${ }^{1}$ Guoliang Wang, ${ }^{5,6}$ and \\ Daoxin Xie $\mathrm{Xi}^{1,2}$ \\ ${ }^{1}$ Institute of Molecular and Cell Biology, 61 Biopolis drive, 138673 Singapore; ${ }^{2}$ Department of Biological Sciences, National \\ University of Singapore, 117543 Singapore; ${ }^{3}$ College of Bio-Safety Science and Technology, Hunan Agricultural University, \\ 410128 China; ${ }^{4}$ Department of Plant Pathology, South China Agricultural University, 510642 China; ${ }^{5}$ Rice Genomics \\ Laboratory, Hunan Agricultural University, 410128 China; ${ }^{6}$ Department of Plant Pathology, The Ohio State University, \\ Columbus, $\mathrm{OH} 43210$, U.S.A.
}

Submitted 8 June 2005. Accepted 15 August 2005.

\begin{abstract}
The F-box protein gene COII from Arabidopsis plays a fundamental role in response to jasmonates, which regulate plant root growth, pollen fertility, wounding and healing, and defense against pathogens and insects. Null mutations in $C O I 1$ were previously found to abolish all the jasmonate responses, and the Arabidopsis coil-1 mutant is male sterile and susceptible to pathogen infection. In this study, we isolated an F-box protein gene from soybean, which shares significant homology with the Arabidopsis COII and similarly contains an $\mathbf{F}$-box motif and leucine rich repeats (LRR), here designated GmCOI1 (Glycine max L. (Merr.) COI1). To test whether the sequence homology and structural similarity are indicative of functional conservation, we expressed $\mathrm{GmCOI1}$ in the Arabidopsis coil-1 mutant. The transgenic coil-1 plants with expression of the GmCOII gene were found to exhibit normal jasmonate responses, including jasmonate-regulated plant defense and fertility. In addition, the chimerical proteins with swapped domain of the F-box motif or LRR between GmCOI1 and COI1 were shown to functionally complement the coil-1 mutation. Furthermore, GmCOI1 was found to assemble into the Skp1-Cullin-F-box (SCF) complexes, similar to the

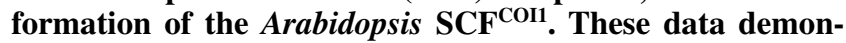
strate the soybean F-box protein gene $\mathrm{GmCOII}$ is able to mediate jasmonate-regulated plant defense and fertility in Arabidopsis, which implies a generic jasmonate pathway with conserved signal components in different plant species.
\end{abstract}

Plant hormones influence diverse developmental processes, ranging from seed germination to root, leaf, shoot, and flower formation. Jasmonates (JA), including jasmonic acid and its cyclopentanone derivatives, are a newly discovered class of plant hormones that are widely distributed in the plant kingdom. JA are synthesized from linolenic acid in a lipoxygenasedependent biosynthetic pathway, in which linolenic acid is oxygenated by lipoxigenase (LOX) and then is converted to 12-oxo-phytodienoic acid by allene oxide synthase (AOS) and

Corresponding author: Daoxin Xie; E-mail: daoxin@imcb.a-star.edu.sg; Telephone: 65-65869621; Fax: 65-68727517.

Nucleotide sequence data for GmCOII has been deposited in the GenBank database under accession number bankit722901. allene oxide cyclase (AOC), and is finally converted to jasmonic acid through reduction and three steps of $\beta$-oxidation (Creelman and Mullet 1997; Staswick 1992). MeJA (methyl JA)was first discovered in the floral scent of jasmine; subsequent studies have demonstrated the presence of JA in all higher plants tested, including Arabidopsis, maize, potato, rice, soybean, tobacco, and tomato (Bell et al. 1995; Creelman et al. 1992; Engelberth et al. 2003; Schmelz et al. 2003; Seto et al. 1996; Weber et al. 1997). Many JA biosynthetic genes isolated from different plant species have been characterized and have been found to be functionally conserved, such as $L O X$ from Arabidopsis (Bell et al. 1995), barley (Voros et al. 1998), potato (Royo et al. 1999), soybean (Bell and Mullet 1991), tomato (Heitz et al. 1997), and wheat (Bohland et al. 1997), AOS from Arabidopsis, barley, flax, guayule, Nicotiana attenuata, rice, tomato (Ha et al. 2002; Harms et al. 1995; Itoh et al. 2002; Kubigsteltig et al. 1999; Sivasankar et al. 2000), and AOC from Arabidopsis (Stenzel et al. 2003b), barley (Maucher et al. 2004), and tomato (Stenzel et al. 2003a).

JA are well-known to act as a regulator in plant growth and development as well as a signal in plant defense and wound responses. They are involved in regulating the expression of numerous genes and influencing diverse processes including pollen development, fruit ripening, root growth, tendril coiling, wound responses, and resistance against insects and pathogens (Creelman and Mullet 1997; Liechti and Farmer 2002; Mandaokar et al. 2003; Reymond and Farmer 1998; Staswick 1992; Vijayan et al. 1998; Wasternack and Parthier 1997). The JA responses were found in a variety of plant species, such as Arabidopsis, barley, maize, soybean, tomato, and wheat (Cordero et al. 1994; Creelman and Mullet 1997; Ma and Wang 2003; Rakwal et al. 2001; Reinbothe et al. 1993). A wide range of genes are regulated by JA, including vegetative storage proteins, thionin, defensin, and pathogenesis-related proteins from various plants, such as Arabidopsis, maize, rice, and soybean (Berger et al. 1995; Chen et al. 2002; Cordero et al. 1994; He et al. 2004; Jwa et al. 2001; Manners et al. 1998; Mason and Mullet 1990; Rakwal and Komatsu 2000; Santamaria et al. 2001; Vignutelli et al. 1998).

Various JA responses have been defined through analysis of genetically identified mutants, including jarl (Staswick 1992; Staswick et al. 1998), coil (Feys et al. 1994), jin (Berger et al. 1996), fad3-2 fad7-2 fad8 (McConn and Browse 1996), opr3 (Sanders et al. 2000; Stintzi and Browse 2000; Stintzi et al. 
2001), cevl (Ellis et al. 2002), mpk4 (Petersen et al. 2000), cet1-9 (Hilpert et al. 2001), cexl (Xu et al. 2001), jue1, jue2, and jue 3 (Jensen et al. 2002), iopl (Penninckx et al. 2003) and others (Lee and Howe 2003; Li et al. 2001, 2002). The jarl and jin mutants exhibit decreased sensitivity to JA; JAR1 encodes an enzyme with JA adenylation activity (Staswick et al. 2002), while JIN1 encodes a MYC transcription factor functional in JA and abscisic acid signaling and is essential to JA and ethylene-regulated defense responses (Abe et al. 2003; Anderson et al. 2004; Boter et al. 2004; Lorenzo et al. 2004). The coil-1 mutant is male sterile, insensitive to JA, and lacks the expression of JA-induced genes (Benedetti et al. 1995; Feng et al. 2003; Feys et al. 1994; Penninckx et al. 1998; Xie et al. 1998). The identification of COI1 as an F-box protein pointed to the involvement of the ubiquitination pathway in JA signaling (Xie et al. 1998). The F-box protein COI1 is able to associate with Arabidopsis SKP1-like proteins ASK1 and ASK2, AtCUL1, and RBX1 in planta (Xu et al. 2002).

In this study, we isolated GmCOII from soybean (Glycine $\max$ L. (Merr.)), which shares significant homology with the Arabidopsis COII sequence and also similarly contains an Fbox motif and leucine rich repeats (LRR). To test whether the sequence homology and structural similarity are indicative of functional conservation, we expressed GmCOII in the Arabidopsis coil-1 mutant, and found that GmCOI1 is capable of substituting COI1 and assembling into the Skp1-Cullin-F-box (SCF) complexes to restore normal JA responses, including JA-regulated plant defense and fertility in the coil-1 mutant of Arabidopsis, suggesting a functional conservation of $\mathrm{COII}$ in soybean and Arabidopsis and implying a generic JA pathway with conserved signal components in different plant species.

\section{RESULTS}

\section{GmCOII is an F-box protein gene} and highly related to $\mathrm{COII}$.

To investigate the potential conservation of the COI1-mediated JA signal transduction in the plant kingdom, we performed the BLAST search to identify the sequences highly homologous to COII in GenBank or the expressed sequence tags (EST) databases. As a result, we identified soybean EST fragments that are highly identical to COII. We then obtained the full coding sequence by screening the soybean cDNA library with the EST fragment as a probe and by sequencing these isolated cDNA clones. Sequence analysis indicated that the identified gene is structurally similar to COI1, having both the Fbox motif and the LRR domain; it shares significant identity, $68.5 \%$ with COI1 (Xie et al. 1998), 70\% with LeCOI11 (the tomato homolog of COI1) (Li et al. 2004), and 57.3\% with OsCOI1 (Oryza sativa COI1) (the rice homolog of COI1) (Figs. 1A and 2A); this gene is here referred to as GmCOII (Glycine max L. (Merr.) COI1). In summary, GmCOI1 exhibits significant structural similarity and strong sequence homology with the Arabidopsis COI1, suggesting that GmCOII may be a COIl-like gene and bear COI1 function as an F-box protein assembled into SCF complexes essential for JA signaling.

\section{Transient expression of GmCOII in coil-1 restores $\mathrm{COI1}$-dependent activation of the JA-responsive reporter Thi2.1:GUS.}

In Arabidopsis, transient expression of COII is able to complement the coil-1 mutation (Xie et al. 1998) in activation of expression of many COI1-dependent genes such as Thi2.1, a gene that encodes an antimicrobial protein. To efficiently test whether the GmCOII is functionally similar to Arabidopsis $C O I 1$, we introduced $G m C O I 1$, which was driven by the cauliflower mosaic virus (CaMV) 35S constitutive promoter (Fig.
2A), into the coil-1 plants transgenic for the Thi2.1 promoterdriven $\beta$-glucuronidase gene $(G U S)$ reporter (referred to as coil-1;Thi2.1:GUS) by particle bombardment (Xie et al. 1998). Histochemical staining revealed sites of transformation as blue spots of GUS activity in leaves of the coil1;Thi2.1:GUS plants, indicating transient complementation of coil-1 by the introduced genes (Xie et al. 1998). The results shown in Figure 2B clearly demonstrated that GmCOII, like COI1, was able to activate the Thi2.1 promoter to drive GUS expression in the coil-1;Thi2.1:GUS plants. As expected, the control vector or the cloned coil-1 mutant fragment failed to complement coil-1 under the identical condition (Fig. 2) (Xie et al. 1998). These results suggest that $G m C O I 1$ is functionally similar to $\mathrm{COI} 1$ in activation of the COI1-dependent gene expression.

\section{Transgenic expression of $\mathrm{GmCOII}$}

in coil-1 restores normal JA sensitivity and male fertility.

To further investigate whether GmCOII is functionally similar to $\mathrm{COII}$ in all JA responses, including JA sensitivity and male fertility, we created stable transgenic coil-1 plants expressing the Myc-tagged GmCOII (referred to as coil-1;GmCOI1). As coil-1 homozygous mutant plants are not suitable for plant transformation (Xie et al. 1998), we first introduced the Myctagged GmCOII driven by the CaMV $35 \mathrm{~S}$ constitutive promoter and other control constructs, including empty vector and the Arabidopsis COII gene driven by the CaMV 35S promoter into coil-1 hetrozygous plants. The coil-1 homozygous mutant plants expressing the transgenes, including GmCOII (coil1;GmCOI1), vector (coil-1:vector), and COI1 (coil-1;COI1) were verified using the coil-1-specific cleaved amplified polymorphic sequence (CAPS) marker (Xie et al. 1998) (Fig. 3A) and then were examined by Western blot analysis (Fig. 3B). Three independent coil-1;GmCOI1 lines (GMC1 through GMC3) were used for further analysis.

To verify the Thi2.1:GUS expression patterns from transient complementation shown in Figure 2B, we introduced the Thi2.1 promoter-driven GUS reporter (Thi2.1:GUS) from the Thi2.1:GUS transgenic plant (Xie et al. 1998) into the GMC1 line (coil-1;GmCOI1) as well as the control lines VEC1 (coil1:vector) and the ARC1 line (coil-1;COI1) via genetic crossing. As shown in Figure 3C, the Thi2.1:GUS activity was clearly detected in the coil-1;GmCOI1;Thi2.1:GUS plants (GMC1) and the coil-1;COI1;Thi2.1:GUS plants (ARC1) but not in the coil-1;vector;Thi2.1:GUS plants (VEC1), consistent with the data shown in Figure 2B.

To further examine whether the Thi2.1:GUS expression patterns are indicative of expression of endogenous Thi2.1 gene in planta, we analyzed the Thi2.1 transcript level, using Northern hybridization. As shown in Figure 3D, the Thi2.1 transcripts were accumulated upon JA induction in the GMC1 line (coil-1;GmCOI1) but not in the control line VEC1 (coil1:vector), consistent with the Thi2.1:GUS expression patterns in the ARC1 line (coil-1;COI1). Moreover, Northern blot analysis revealed that $\mathrm{GmCOI1}$ could functionally substitute COII to mediate the expression of other JA-responsive genes, includeing PDF1.2 and AtVSP (Fig. 3D). Similar results were obtained from other independent transgenic GMC2 and GMC3 lines (Fig. 3D and data not shown). These results indicated that GmCOII is able to functionally substitute COII and mediate the expression of JA-responsive genes in Arabidopsis.

As assayed for JA-inhibitory root growth, three GMC lines (coil-1;GmCOI1) all exhibited JA sensitivity at a level similar to the ARC1 line (coil-1;COI1), whereas the VEC1 line (coil1 ; vector) was resistant to JA (Fig. 3E and data not shown), demonstrating that the GmCOII is able to fully substitute Arabidopsis COII to mediate JA sensitivity. 
The coil-1 mutant is deficient in the production of viable pollen grains causing male sterility (Feys et al. 1994; Xie et al. 1998); therefore, we examined whether GmCOII is able to functionally complement the defects of pollen development in coil-1. Three GMC lines (coil-1;GmCOI1), similar to the ARC1 line (coil-1;Myc-COI1), were able to produce viable pollen grains and generated fertile siliques (Fig. 3F). These re- sults demonstrate functional conservation of $\mathrm{COII}$ and GmCOII in modulation of pollen development.

Transgenic expression of $\mathrm{GmCOII}$

in coil-1 restores plant defense.

The coil-1 mutations were previously found to cause loss of plant defense responses (McConn et al. 1997; Norman-Setterblad

\begin{abstract}
F-box
LeCOI1 MEERNSTRLS---SS-----TNDTVWECVIPYIQESRDRDAVSLVCKRWWOIDAITRKHITMALCYTAK 61

GmCOI1 MTEDRNVR-K---TR-----VVDIVIDCVIPYIDDPKDRDAVSOVCRRWYEIDSLTRKHVTIALCYTTT 60

A tCOI1 MEDPDIKRCKLSCVA-----TVDDVIEOVMTYITDPKDRDSASLVCRRWFKIDSETREHVTMALCYTAT 64

OsCOI1 MGGEVPEPRRLNRALSFDDWVPDEALHLVMGHVEDPRDREAASRVCRRWHRIDALTRKHVTVAFCYAAR 69

LeCOI1 PEQLSRRFPHLESVKLKGKPRAAMFNLIPEDWGGYVTPWVMEITKSFSKLKALHFRRMIVRDSDIELLA 130

GmCOI1 PARIRRRFPHLESLKLKGKPRAAMFNLIPEDWGGHVTPWVKEISQYFDCLKSLHFRRMIVKDSDIRNLA 129

AtCOI1 PDRLSRRFPNLRSLKLKGKPRAAMFNLIPENWGGYVTPWVTEISNNIRQLKSVHFRRMIVSDIDIDRLA 133

OsCOI1 PARIRERFPRLESISLKGKPRAAMYGLIPDDWGAYAAPWIDEAAPLECLKALHIRRMTVTDADIAALV 138

LeCOI1 NRRGRVLOVLKLDKCSGFSTDGLLHISRSCKNLRTLIMEESYIIEKDGEWAHELALNNTVLENLNFYMT 199

GmCOI1 RDRGHVIHSLKLDKCSGFTTDGLFHIGRFCKSLRVIFLEESSIVEKDGEWLHELALNNTVLETLNFYIT 198

AtCOI1 KARADDLETLKLDKCSGETTDLISIVTHCRKIKTLIMEESSF SEKDGKWLHELA EHNTSLEVILNFYMT 202

OsCOI1 RARGHMLOELKLDKCIGFSTDALRLVARSCRSLRTLFLEECHITDKGGEWLHELANNNSVIVTLNFYMT 207

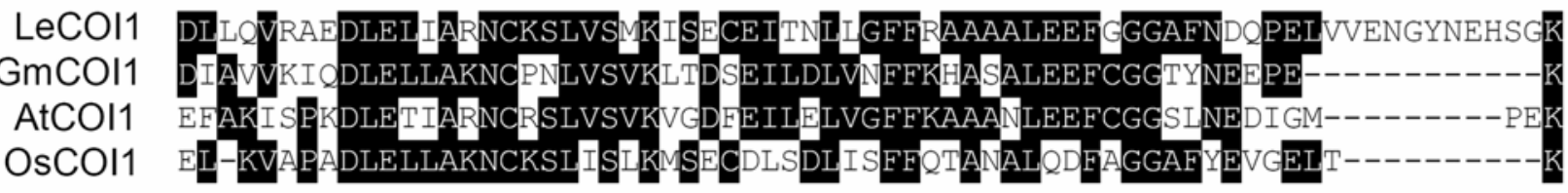

LeCOI1 YAALVFPR LCOLGLTYLGRNEMSILFPIASRIRKLDLLYALLDTAAHCFLIERCPNLEILETRNVVGD GmCOI1 YSAISIPAKLCRLGLTYIGKNELPIVGMAAVLKKLDLLYAMLDTEDHCMLIQKCPNLEVLETRNVIGD

AtCOI1 YMNLVFPRKLCRLGLSYMGENEMPILFPFAAQIRKLDLLYALLETEDHCTLIQKCPNLEVLETRNVIGD

OsCOI1 YEKVKFPPRLCFLGLTYMGTNEMPVIFPESMKLKKLDIEYTELTTEDHCOIIAKCPNLLILEVRNVIGD

268

255

262

265

LeCOI1 RGLEVLGQYCKRLKRLRIERGADDQEMEDEEGAVTHRGLIDLAKGCLELEYMAVYVSDITNEALEVIGT

GmCOI1 RGLEVLGRCCKRLKRLRIERGDDDQGMEDEEGTVSHRGLIALSQGCSELEYMAVYVSDITNASLEHIGT

AtCOI1 RGLEVIAQYCKOLKRLRIERGADEGGMEDEEGLVSQRGLIALAQGCOELEYMAVYVSDITNESLESIGT

OSCOI1 RGLEVVGDTCKKLRRLRIERGDDDPGLEEEGGVSOIGLTAVAAVGCREEYIAAYVSDITNGALESIGT

337

324

331

334

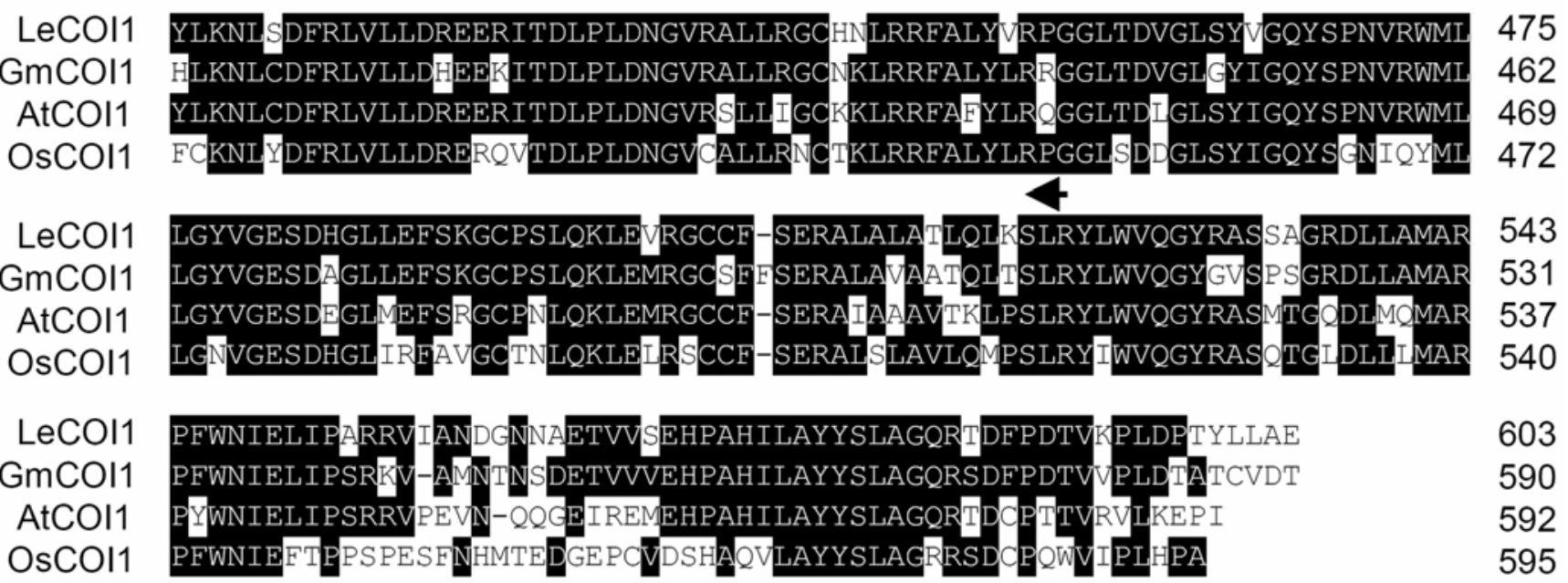

Fig. 1. Sequence comparison between AtCOI1 from Arabidopsis (AAB95279.1), GmCOI1 from soybean, LeCOI1 from tomato (AAR82925.1), and OsCOI1 from rice (BAD81943.1). Black boxes represent identical residues. The F-box domain is marked with one single solid line, while the leucine-rich repeats domain is located between the two inverted arrows. 
et al. 2000; Stintzi et al. 2001; Thomma et al. 1998; Vijayan et al. 1998). To test whether GmCOII is able to restore JA-regulated defense responses in the Arabidopsis coil-1 mutant plants, we inoculated Botrytis cinerea onto the coil-1 plants transgenic for GmCOII (coil-1;GmCOI1), the Myc-tagged Arabidopsis COII (coil-1;Myc-COI1), and vector (coil-1;vector). As expected, all the seedlings from VEC1 (coil-1;vector) were dead (100\%) 14 days after pathogen inoculation, whereas those from the ARC1 line (coil-1;Myc-COI1) were resistant to these pathogens, exhibiting only approximately $5 \%$ death rate under identical treatment (Fig. 4A). The coil-1;GmCOII transgenic lines, including GMC1, all displayed disease resistance by showing only a $4.5 \%$ death rate, similar to that of the ARC1 line (Fig. 4A and data not shown). Consistent with the phenotypes of disease resistance, expression of the defense-related genes, such as the plant defensin $P D F 1.2$, upon pathogen inoculation was observed in the coil-1;GmCOII and coil-1;Myc-COI1 transgenic plants but not in the coil-1;vector plants (Fig. 4C). These data suggest that the GmCOIl restores the plant defense in the Arabidopsis coil-1 mutant plants. A similar conclusion was reached when we tested the GMC1 line (coil-1;GmCOI1) for the plant resistance against the bacterium Erwinia carotovora (Fig. 4B).

\section{Domain swapping of the F-box motif} and the LRR domain between COI1 and GmCOI1.

GmCOIl is speculated to encode F-box proteins that are structurally similar to COI1, containing an F-box motif and 16

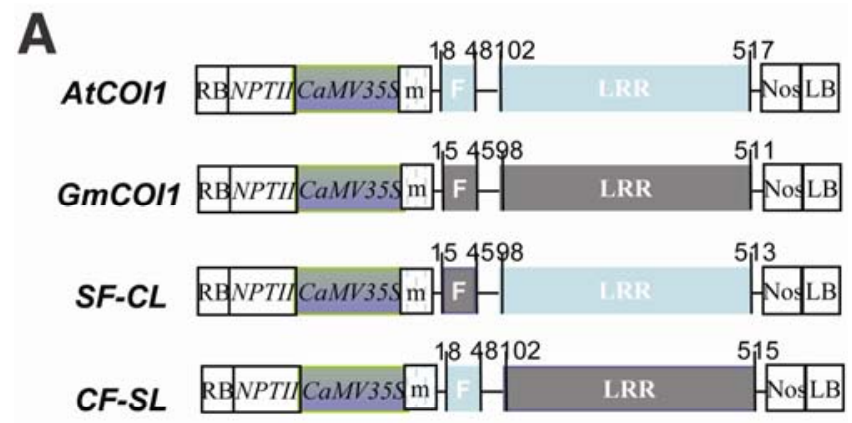

\section{B}

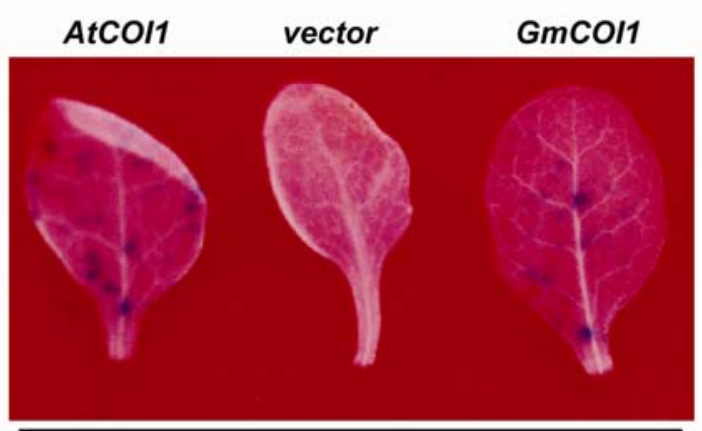

coi1-1;Thi2.1:GUS

Fig. 2. Plasmid constructs and transient complementation. A, Plasmid constructs. AtCOI1, GmCOII, SF-CL, and CF-SL genes were 5' myc tagged $(\mathrm{m})$ under control of the cauliflower mosaic virus $35 \mathrm{~S}$ promoter. $S F-C L$ consists of the F-box domain (F) from GmCOI1 and the leucinerich repeat (LRR) domain from COI1, whereas $C F-S L$ contains the F-box domain from COI1 and the LRR domain from GmCOI1. The numbers indicate the locations of the amino acid residues. The schematic diagram is not on scale. B, Particle bombardment in the coil-1;Thi2.1:GUS plants with the plasmid constructs AtCOII and GmCOII described in A. The vector $p M Y C 2$ was used as a control. The blue spots indicated positive $\beta$ glucuronidase activity (Xie et al. 1998).
LRR (Fig. 1A). To further analyze the functional conservation of their F-box and LRR domains, we in-frame fused the F-box motif of soybean COIl to the LRR domain of Arabidopsis COII, resulting in a chimerical gene designated $S F-C L$ (soybean COII F-box-COI1 LRR). We also swapped with the Arabidopsis COIl F-box motif in the soybean $C O I 1$ to generate another chimerical gene designated as $C F$-SL (COII F-box-soybean COII LRR) (Fig. 2A). Similar to generation and characterization of coil-1;GmCOI1 transgenic plants, we created the coil-1 transgenic plants expressing the $S F-C L$ and $C F-S L$ chimerical genes, which were designated as coil-1;SF-CL and coil-1;CF-SL, respectively. Three independent lines for each transgenes (SFCL1 to SFCL3 for coil-1;SF-CL and CFSL1 to CFSL3 for coil$1 ; C F-S L)$ were used for further analysis and were found to display similar results. The data from the transgenic lines SFCL1 and CFSL1 are shown in Figure 3.

As assayed for JA-inducible gene expression revealed by Northern blot analysis (Fig. 3D) and for JA inhibitory effect on root elongation (Fig. 3E), pollen development, and plant fertility (Fig. 3F), we found that $S F-C L$ and $C F-S L$ complemented the coil-1 mutation. When assayed for resistance against the fungus Botrytis cinerea (Fig. 4A) and against the bacterium Erwinia carotovora (Fig. 4B), the coil-1;SF-CL and coil$1 ; C F-S L$ transgenic plants exhibited resistance, though resistance level is lower than that conferred by $M y c-C O I 1$ or GmCOI1. Consistently, the plant defensin PDF1.2 transcripts upon pathogen infection were accumulated in the coil-1;SF$C L$ and coil-1;CF-SL transgenic plants (Fig. 4C and D), though at a lower level than that in the coil-1;Myc-COII or coil-1;GmCOI1 plants (Fig. 4). These results further demonstrate the functional conservation of the F-box and LRR domains in the GmCOI1 and Arabidopsis COI1.

\section{Formation of GmCOI1-containing SCF complexes.}

The F-box protein COI1 was found to interact with the Arabidopsis SKP1-like proteins ASK1 and ASK2 in the yeast two-hybrid system and to associate with AtCUL1 and ASK1 or ASK2, assembling the $\mathrm{SCF}^{\mathrm{COI}}$ complexes that mediate JA signal transduction in Arabidopsis (Xu et al. 2002). To test whether GmCOI1 in Arabidopsis is able to form SCF complexes similar to $\mathrm{SCF}^{\mathrm{CO} 1}$, we used the yeast two-hybrid system and coimmunoprecipitation assay to examine the interaction of GmCOI1 with SCF components. As shown in Figure 5A, the soybean COI1 was also able to interact with Arabidopsis ASK1 and ASK2 in the yeast two-hybrid system, which is similar to the interaction of COI1 with ASK1 and ASK2. As revealed by coimmunoprecipitation assay, the GmCOI1 was found to associate with AtCUL1, RBX1, ASK1, or ASK2 and form SCF complexes in the coil-1;GmCOI1 transgenic plants (Fig. 5B and data not shown). These data demonstrate that GmCOI1 is capable of substituting COI1 and assembling into the SCF complexes in Arabidopsis, suggesting that the COI1 orthologs may mediate JA responses in different plant species via $\mathrm{SCF}$ formation similar to $\mathrm{SCF}^{\mathrm{COI1}}$.

\section{DISCUSSION}

The model organism Arabidopsis has been used as a powerful system to study Arabidopsis homologous genes from other species through ectopic expression, particularly the availability of many well-characterized Arabidopsis mutants offered a unique opportunity to investigate the predicted function of the homologous genes from other species via heterologous expression. This approach has been successfully used for functional analysis of LeCTR1, a tomato gene with strong homology to the Arabidopsis CTRl essential for ethylene signal transduction, which was expressed in the ethylene response-deficient 
A

WT ARC1 VEC1 GMC1 SFCL1 CFSL1

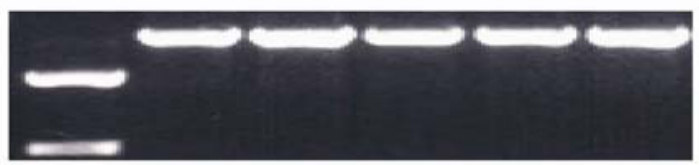

B
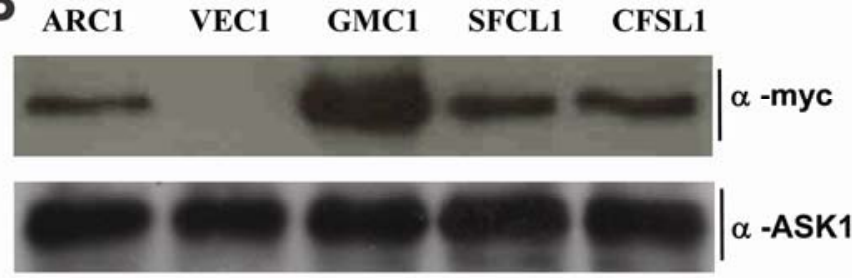

\section{ARC1 VEC1 GMC1 SFCL1 CFSL1}

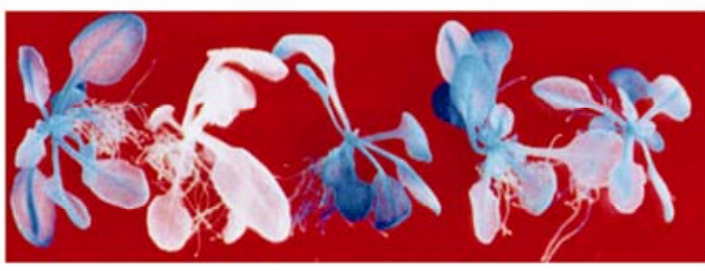

coi1-1;Thi2.1:GUS;

D
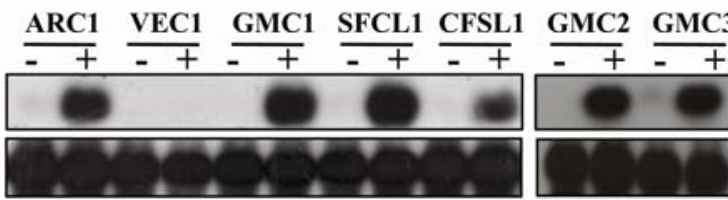

JA

PDF1.2

18S rRNA
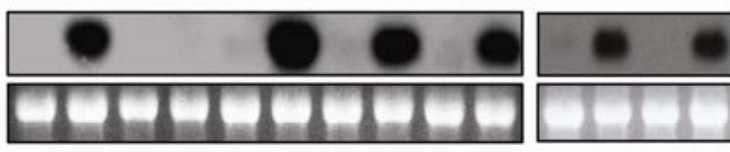

Thi2.1

28S rRNA

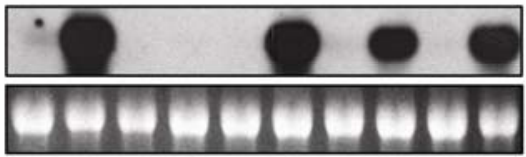

E
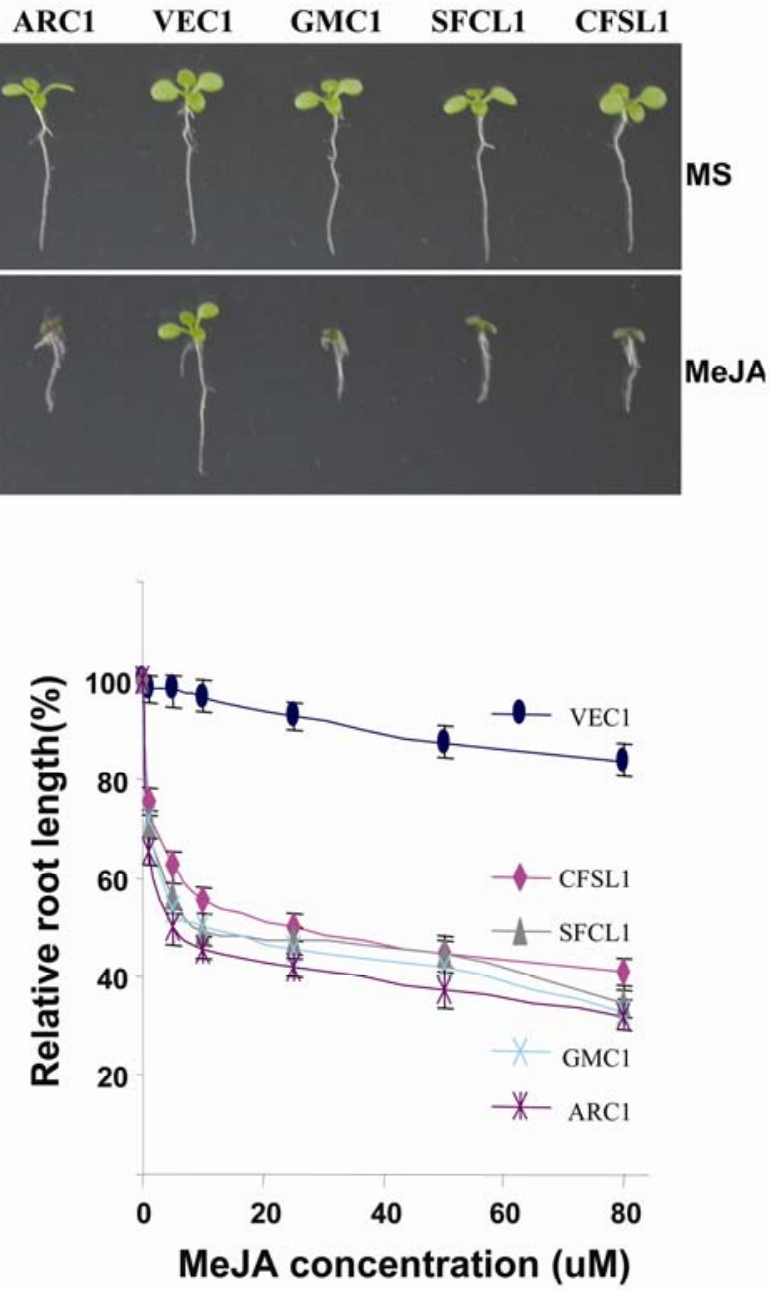

$\mathbf{F}$
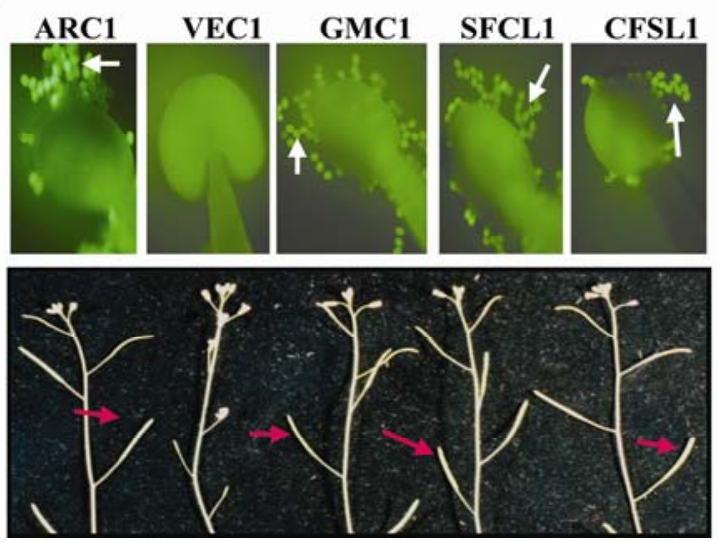

Fig. 3. GmCOII, SF-CL, and CF-SL restore jasmonate (JA) sensitivity and pollen fertility in the Arabidopsis coil-1 mutant. A, The transgenic lines transformed with the constructs containing AtCOI1, GmCOI1, SF-CL, or CF-SL genes were homozygous for coil-1, which was revealed by the coil-1specific cleaved amplified polymorphic sequence markers. WT $=$ wild type (Arabidopsis Columbia), The VEC1 line $=$ the coil-1 mutant transgenic for the pMYC2 vector. The transgenic lines ARC1, GMC1, SFCL1, or CFSL1 represent the coil-1 plants transgenic for the constructs AtCOI1, GmCOI1, SF-CL, and $C F-S L$, respectively. B, Western analysis of the transgenic lines mentioned in A. Top panel: the Myc-fused proteins were detected with Myc antibody ( $\alpha$ myc). Bottom panel: the ASK1 protein detected by the $\alpha$-ASK1 antibody was used as loading control. C, The coil-1;Thi2.1:GUS plants containing the constructs AtCOI1 (the ARC1 line), GmCOI1 (the GMC1 line), SF-CL (the SFCL1 line), or CF-SL (the CFSL1 line) were examined for $\beta$-glucuronidase activity upon JA induction. D, Northern analysis of the JA-treated (+) or untreated (-) transgenic lines probed with PDF1.2, Thi2.1, and AtVSP. 18S rRNA or 28S rRNA was provided as the loading control. E, Phenotypes of nine-day-old seedlings grown on the plant growth (MS) medium or the medium containing $25 \mu \mathrm{M}$ methyl (Me)JA (top panel). The bottom panel represents the MeJA dose-response curve of root growth. Root length of the indicated seedlings grown on medium containing various MeJA $(5,10,25,50$, or $80 \mu \mathrm{M})$ for 9 days was expressed as a percentage of root length grown on MS. Each datapoint is the mean of more than 30 samples. The experiment was repeated three times. Error bars represent standard deviation $(n>30)$. F, The $G m C O I 1, S F-C L$, and $C F-$ $S L$ transgenes are able to restore fertility in coil-1. The arrows in the top panel indicate the viable pollen grains in anthers from the transgenic plants indicated, which were stained with $1 \%$ fluorescein diacetate and were visualized under fluorescence microscopy. The arrows in the bottom panel indicate fertile siliques from the plants described. 
A

ARC1 VEC1 GMC1 SFCL1 CFSL1
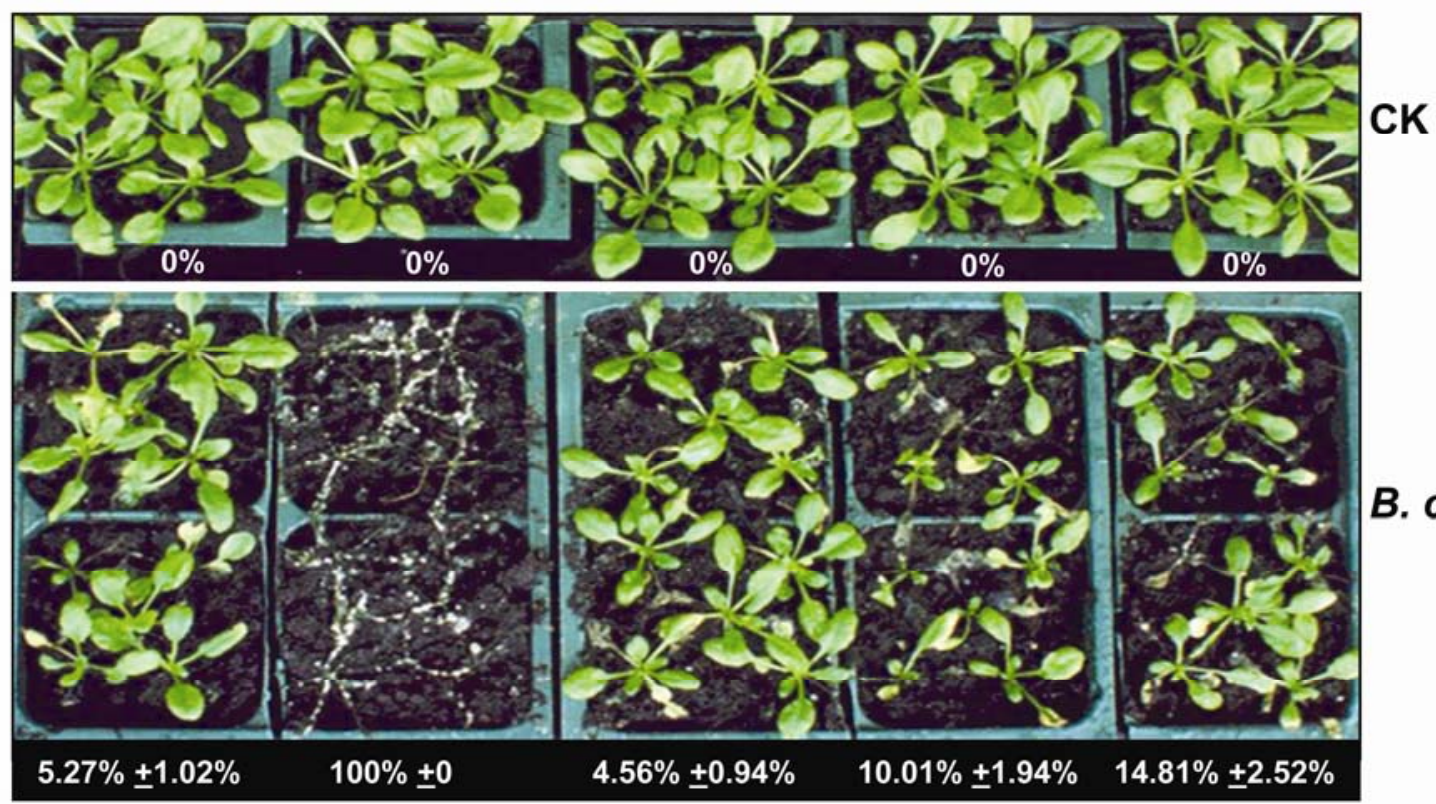

B. $C$

B
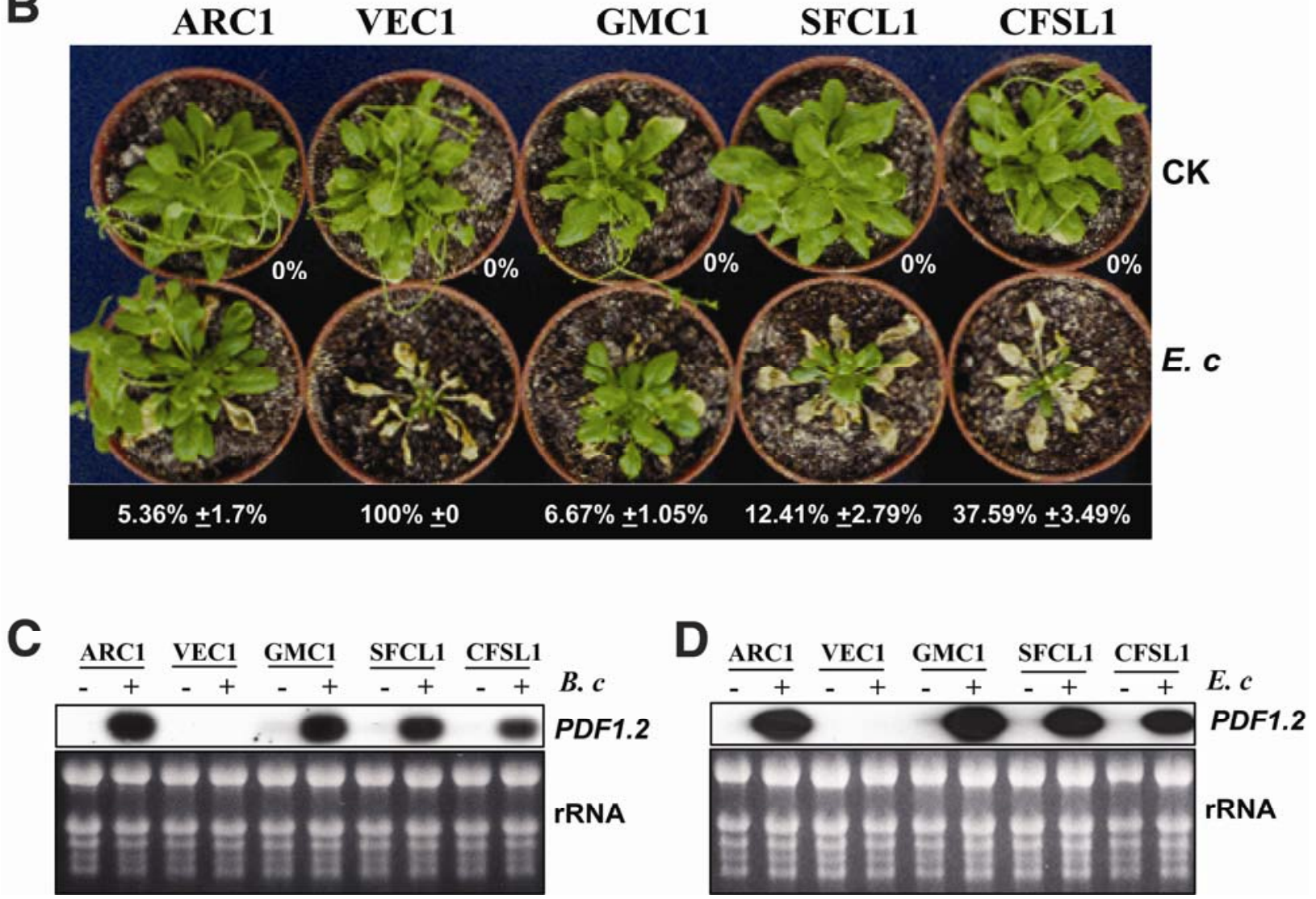

Fig. 4. GmCOI1, $S F$-CL, and $C F-S L$ are able to restore jasmonate-regulated defense responses in the Arabidopsis coil-1 mutant. A, Two-week-old seedlings were inoculated with Botrytis cinerea (B. c) (bottom panel) or 1\% D-Glucose (CK) (top panel) and were photographed on the 14th day after inoculation. The death rate and standard deviation $(n>40)$ for each line are indicated, except when standard deviation is 0 . The experiment was repeated seven times. B, Three-week-old seedlings were inoculated with Erwinia carotovora (E. c) (bottom panel) or Luria-Bertani (LB) medium (CK) (top panel) and were photographed on the 14th day after inoculation. The death rate and standard deviation $(n>40)$ for each line are indicated, except when standard deviation is 0 . The experiment was repeated seven times. C, Northern blot analysis of the expression of plant defense gene PDF1.2 in the indicated transgenic lines inoculated without $(-)$ or with $(+)$ Botrytis cinerea $($ B. c). D, Northern blot analysis of the expression of plant defense gene PDF1.2 in the indicated transgenic lines inoculated without (-) or with (+) Erwinia carotovora $($ E. $c)$. 
mutant ctrl-1 of Arabidopsis and was found to be capable of restoring normal ethylene signaling (Leclercq et al. 2002). Here, we used a similar approach to carry out functional analysis of GmCOIl, which is isolated from soybean and highly homologous to the Arabidopsis COII. We demonstrate that GmCOII from soybean is capable of substituting AtCOII and mediating JA-regulated plant defense and fertility in Arabidopsis.

F-box proteins are generally composed of a conserved Fbox motif at N-termini and a protein-protein interaction motif such as LRR, WD40, or Kelch repeats at C-termini and have been widely identified in mammals, plants, and yeast (Deshaies 1999; Hershko and Ciechanover 1998). In Arabidopsis, nearly 700 potential F-box genes have been identified (Gagne et al. 2002). Several F-box genes have also been characterized in other plant species, including rice (Sasaki et al. 2003), tomato (Li et al. 2004), Antirrhinum (Lai et al. 2002; Simon et al. 1994), pea (Taylor et al. 2001), Lotus (Zhang et al. 2003), almond, and cherry (Entani et al. 2003; Ushijima et al. 2003; Yamane et al. 2003). However, there is no information regarding molecular cloning of F-box genes in soybean. In this work, for the first time, we isolated the Fbox gene GmCOII from soybean and established the biological functions for the homolog of $\mathrm{COI}$ from other plant species in JA signaling in Arabidopsis. Through transient or transgenic expression, or both, of $\mathrm{GmCOI1}$, the soybean homolog of COII, in the JA-response-deficient mutant coil-1 of Arabidopsis, we found that GmCOIl is capable of complementing the coil-1 mutation and restoring normal JA responses, including plant defense and fertility. These results suggest that $G m C O I 1$ is functionally conserved with the COI1, implying that COI1-mediated JA signaling pathways may be conserved in different plant species. Our finding is in good agreement with the previous studies that the JA biosynthesis and inducible genes are quite conserved in different plant species.

Despite the functional conservation, developmental and evolutionary modification among different plant species may influence JA responses and alter biological functions for the homologous genes of COII in the corresponding host plant. It is noticeable to point out a discrepancy in JA responses between Arabidopsis and tomato. The Arabidopsis mutants defective in JA biosynthesis (fad3-2 fad7-2 fad8, dad1, dde1/opr3) or perception (coil-1) are male sterile (Feys et al. 1994; Ishiguro et al. 2001; McConn and Browse 1996; Sanders et al. 2000; Stintzi et al. 2001), whereas tomato mutants apparently defective in JA biosynthesis (def-1, spr-1, spr-2) or perception (jail) are male fertile (Lee and Howe 2003; Li et al. 2001, 2002), suggesting that the Arabidopsis COI1 partner, which is essential for pollen development, may be altered in tomato and other specific components or signal pathways have been evolutionarily developed to mediate pollen development in tomato. Indeed, the recently identified tomato homolog of COII (LeCOI1) from the mutant jail is essential for JA-regulated gene expression and defense response but is not necessary for pollen development (Li et al. 2004). It was reported that the jail mutant exhibited reduced pollen viability and the sterility was caused by a defect in the maternal control of seed maturation, which was associated with the loss of accumulation of JA-regulated proteinase inhibitor proteins in reproductive tissues ( $\mathrm{Li}$ et al. 2001, 2004). Recently, a rice mutant, hebiba, was found to display impaired induction of the JA pathway and exhibit male sterility (Riemann et al. 2003), suggesting that the COI1-regulated pollen fertility might be conserved in rice and Arabidopsis. Identification and characterization of rice mutant with mutation in $\mathrm{OsCOII}$ would further test the possible conservation in JA responses between rice and Arabidopsis.
The SCF complex is composed of four subunits, Cullin/ Cdc53, SKP1, RBX1/ROC1/HRT1, and a variable component F-box protein (Deshaies 1999; Hershko and Ciechanover 1998). Except for this structural conservation, the homologs of the SCF core components from different species are likely conserved in the basic function. For example, disruption of Cullin caused similar developmental defects in embryogenesis in mice (Dealy et al. 1999; Wang et al. 1999) and Arabidopsis (Shen et al. 2002; Ren et al. 2005), yet there were some differences due to evolutionary modification. It is interesting to know whether the homologs of F-box genes from different species share similar functions. Several homologs of F-box genes among the plant species have been characterized. The Arabidopsis unusual floral organs (UFO) (Samach et al. 1999) shares conserved function with the UFO orthologs from pea (Taylor et al. 2001), Antirrhinum (Ingram et al. 1997; Simon et al. 1994), and Lotus (Zhang et al. 2003). The F-box gene GID2 from rice and its homologous gene from Arabidopsis (SLY1) exhibited similar function in gibberellin signaling (McGinnis et al. 2003; Sasaki et al. 2003). OsRALyase1, a putative F-box protein from rice, displayed identical enzyme activity as wheat RALyase did (Ito et al. 2002; Ogasawara et al.

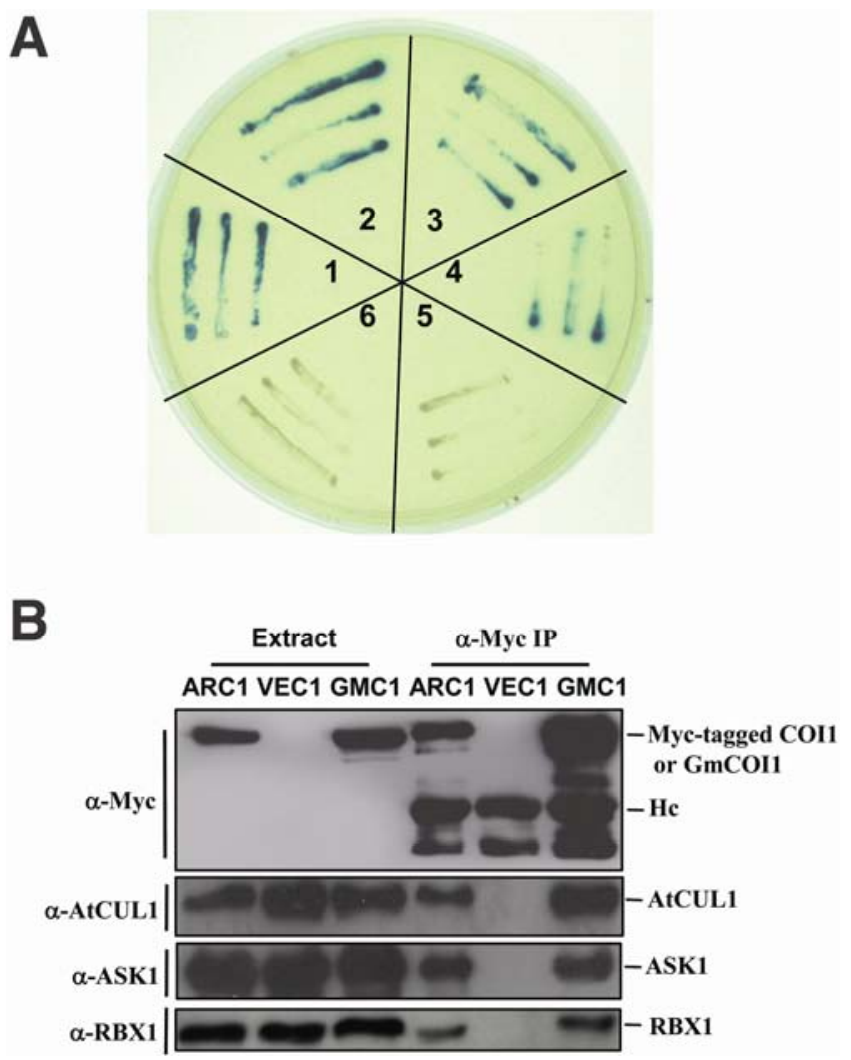

Fig. 5. Formation of GmCOI1-containing Skp1-Cullin-F-box complexes. A, GmCOI1 interacts with ASK1 and ASK2 in the yeast two-hybrid system. 1, pLexA-COI1/pB42AD-ASK1; 2, pLexA-GmCOI1/pB42AD-ASK1; 3, pLexA-COI1/pB42AD-ASK2; 4, pLexA-GmCOI1/pB42AD-ASK2; 5, pLexA-COI1/pB42AD; and 6, pLexA-GmCOI1/pB42AD. Positive interaction of the indicated proteins was revealed by blue color of the colonies showing positive $\beta$-galactosidase activity. $\mathbf{B}$, Coimmunoprecipitation assays. Protein extracts from the indicated transgenic lines ARC1 (coil-1 transgenic plants expressing Myc-tagged COI1) and GMC1 (coil-1 transgenic plants expressing Myc-tagged GmCOI1) were immunoprecipitated (IP) with $\alpha-$ Myc antibody. The resulting immunoprecipitates were analyzed by Western blotting probed with the antibodies $\alpha$-Myc, $\alpha-\operatorname{AtCUL1}$, $\alpha$-ASK1, and $\alpha$-RBX1 (indicated on the left side). The VEC1 line (the coil-1 transgenic for vector) was used as the control to demonstrate the specificity of coimmunoprecipitation assays. $\mathrm{Hc}=$ immunoglobulin heavy chain. 
1999). The homologous F-box genes from the rosaceous species almond and Antirrhinum, and three species of cherry, Prunus cerasus, $P$. avium, and P. mume, all defined the selfincompatibility locus (Entani et al. 2003; Lai et al. 2002; Ushijima et al. 2003; Yamane et al. 2003). Our results, restoration of normal JA-regulated plant defense and fertility by the soybean F-box protein GmCOI1 in Arabidopsis coil-1 mutant plants, provide a clue that $C O I 1$ may be functionally conserved in Arabidopsis and soybean. The results that GmCOI1 interacted with the Arabidopsis COI1-associated proteins and assembled into the SCF complex in Arabidopsis indicate that the COI1 homologs mediate JA responses, probably via SCF complexes in various plant species; yet, the potential differences are not excluded. Combined with the data from other plant Fbox homologous genes characterized, these results indicate a possibility that homologous F-box genes from different plant species might also share similar basic functions. This notion will be determined via further characterization of more F-box homologous genes from various plant species.

\section{MATERIALS AND METHODS}

\section{Identification of $\mathrm{GmCOI1}$ and domain swapping between GmCOI1 and AtCOI1.}

The Arabidopsis COII sequence was used for the BLAST search in the EST databases. Following routine methods, the partial fragments highly identical to $C O I 1$ were identified from soybean EST databases, were subsequently polymerase chain reaction (PCR)-amplified and labeled with $\left[\alpha-{ }^{32} \mathrm{P}\right] \mathrm{dCTP}$ as probes, to screen the soybean (Glycine $\max$ L. (Merr.)) cDNA library (Stratagene, La Jolla, CA, U.S.A.) for the full coding region; the identified cDNA was finally sequenced.

The full-length coding region of the GmCOIl gene was PCR-amplified from the soybean cDNA clone with primers GmCOI1-ATG (5'-ATGACGGAGGATCGGAACGT-3') and GmCOI1-END (5'-CTAGGTGTCAACGCATGTG-3') and were subsequently cloned into the pMYC2 vector with $5^{\prime}$ tagged Myc in sense orientation under control of the CaMV $35 \mathrm{~S}$ promoter (Xu et al. 2002). The Arabidopsis COII was previously Myc-tagged in pMYC2 (Xu et al. 2002).

Domain swapping between GmCOI1 and COI1 was performed by PCR. To fuse the F-box motif of Arabidopsis COII to the LRR domain of soybean $\mathrm{GmCOI1}$, we used primers COI1-ATG (5'-ATGGAGGATCCTGATATC-3') and CS-R (5'GTAGCAGAGCGCGATGGTCACATGCTCTCTCGTCTC-3') to PCR-amplify, from COI1, a 183-bp fragment A containing the COII F-box motif tagged with an 18-bp sequence (underlined in the CS-R primer sequence) identical to the start region of the GmCOI1 LRR. Also, primers CS-F (5'-GAGACGAGAGAGCATGTGACCATCGCGCTCTGCTAC-3') and GmCOI1END were used to PCR-amplify, from $\mathrm{GmCOI1}$, fragment B containing the GmCOI1 LRR tagged with an 18-bp sequence (underlined in the CS-F primer sequence) identical to the end region of the Arabidopsis COII F-box motif. Fragments A and $\mathrm{B}$ were then mixed and used as templates to amplify the chimerical gene using primers COI1-ATG and GmCOI1-END, resulting in the $C F-S L$ gene.

To swap with the soybean COII F-box motif in the Arabidopsis COI1, a similar strategy was used. Primers GmCOI1ATG and SC-R (5'-GTAGCAAAGCGCCATAGTGACGTGC TTCCGAGTGAG-3') were used to amplify fragment A from GmCOI1, and primers SC-F (5'-CTCACTCGGAAGCACGTC ACTATGGCGCTTTGCTAC-3') and COI1-3E (5'-TATCATAT TGGCTCCTTCAG- $3^{\prime}$ ) were used to amplify fragment B from COII. Fragments A and B were mixed to serve as templates to amplify fused fragments, using primers GmCOI1-ATG and COI1-3E, resulting in the $S F-C L$ gene.
The $C F$-SL and $S F$ - $C L$ genes were finally cloned in-frame to pMYC2 in sense orientation under the control of $35 \mathrm{~S}$ promoter following routine methods (Xu et al. 2002).

All the constructs were sequence-verified. The Arabidopsis COI1/coil-1 F1 plants were used in the Agrobacterium-mediated floral infiltration transformation (Bechtold et al. 1993; Bent 2000).

Transient expression assay and GUS histochemical staining as well as pollen grain staining in $0.01 \%$ (wt/vol) fluorescein diacetate (FDA) were described in our previous work (Xie et al. 1998).

\section{coil-1-specific CAPS marker.}

Primers p1 (5'-GGTTCTCTTTAGTCTTTAC-3') and p2 (5'CAGACAACTATTTCGTTACC- $3^{\prime}$ ) were used to amplify the approximately $1.5-\mathrm{kb}$ genomic DNA fragment containing COIl or coil-1 (but not the transgene). As the coil-1 mutation abolishes the XcmI recognition site (Xie et al. 1998), the XcmI was unable to digest the approximately 1.5 -kb PCR fragment amplified from the coil-1-homozygous plants but was able to generate two bands (approximately 0.5 and $1.0 \mathrm{~kb}$ ) for wild type $(\mathrm{COI} / \mathrm{COI1})$ or three bands (approximately $0.5,1.0$, and $1.5 \mathrm{~kb})$ for heterozygous (COI1/coil-1) plants.

All the transgenic plants used in this work were confirmed to be homozygous for coil-1. Three independent transgenic lines with similar expression levels of each transgene were tested and exhibited similar results. We only showed the results obtained from one transgenic line of each transgene in all the figures except for Figure 3D.

\section{Plant growth conditions and treatment.}

Seeds were surface-sterilized, were plated on plant growth (MS) medium, were chilled at $4^{\circ} \mathrm{C}$ for 3 days, and then, were transferred to a growth chamber under a 16-h light (21 to $\left.23^{\circ} \mathrm{C}\right)$ and 8 -h dark $\left(16-19^{\circ} \mathrm{C}\right)$ cycle. For root-length measurement experiments, the seedlings were grown on MS medium supplemented with various concentrations of MeJA (Aldrich, St. Quentin, France) for 9 days before measurement.

\section{Defense assay in Arabidopsis.}

Two-week-old Arabidopsis seedlings were inoculated with a spore suspension from the fungus Botrytis cinerea (provided by Y. D. Choi) (Seo et al. 2001) at a concentration of $1 \times 10^{5}$ spores $/ \mathrm{ml}$ in $1 \% \mathrm{D}$-Glucose (wt/vol), whereas control seedlings were sprayed with $1 \% \mathrm{D}$-Glucose. The plants were placed in a dark chamber for $18 \mathrm{~h}$ at $22^{\circ} \mathrm{C}$ with high relative humidity and were subsequently maintained under an 8-h light and 16-h dark cycle at $22^{\circ} \mathrm{C}$ and high relative humidity. The death rate of the seedlings was recorded on the 14th day after inoculation.

For inoculation of bacterium Erwinia carotovora subsp. carotovora, $1 \mu \mathrm{l}$ of bacterial suspension $\left(2 \times 10^{7} \mathrm{CFU} / \mathrm{ml}\right)$ in $\mathrm{LB}$ liquid medium ( $\mathrm{pH}$ 7.0) was added to each of two wound sites on each leaf of three-week-old seedlings, whereas control seedlings were inoculated with Luria-Bertani (LB) liquid medium. Five leaves from each seedling were inoculated. Plant growth conditions were similar to those used in the inoculation experiment with Botrytis cinerea described above. The death rate of the seedlings was recorded on the 14th day after inoculation.

\section{Plant materials used in Northern blot analysis.}

Two-week-old seedlings on MS medium were treated for 7 h with $100 \mu \mathrm{M} \mathrm{MeJA} \mathrm{(Aldrich)} \mathrm{or} \mathrm{with} \mathrm{distilled} \mathrm{water} \mathrm{as} \mathrm{con-}$ trol, and then, were frozen in liquid nitrogen.

Two-week-old seedlings were inoculated with the fungus Botrytis cinerea (or with $1 \%$ D-Glucose as control). Threeweek-old seedlings were inoculated with the bacterium $\mathrm{Er}$ - 
winia carotovora (or with LB liquid medium as control). After inoculation $(72 \mathrm{~h})$, the plants were harvested and frozen in liquid nitrogen.

Total RNA was isolated from the above materials and was used in Northern hybridization with the digoxigenin-labeled probes PDF1.2, Thi2.1, AtVSP, and $18 S$ rDNA, following the method described in our previous work (Xu et al. 2001; Xu et al. 2002).

\section{Interaction of GmCOI1 with ASK1 and ASK2 in yeast.}

The GmCOII was amplified with primers GmCOI1-BamHI (5'-GAGGATCCTTATGACGGAGGATCGGAACGT-3') and GmCOI1-3ENcoI (5'-GACCATGGCTAGGTGTCAACGCAT GTG-3') and was ligated to the vector pLexA at BamHI and NcoI sites, generating pLexA-GmCOI1. pLexA-COI1, pB42ADASK1, and pB42AD-ASK2 were constructed in our previous study (Xu et al. 2002). These constructs were transferred to the yeast strain EGY48, to detect mutual interaction according to the MATCHMARKER LexA two-hybrid system (Clontech, Palo Alto, CA, U.S.A.) (Xu et al. 2002).

\section{Coimmunoprecipitation in Arabidopsis.}

The coimmunoprecipitation assays and antibodies were described in our previous work (Xu et al. 2002).

\section{ACKNOWLEDGMENTS}

We thank Y. D. Choi for fungal strain Bortytis cinerea and J. Browse for useful help. L. Dai was in part supported by the Department of Science and Technology of Hunan Province, China. This work was supported by a Singapore A*Star (Agency of Science, Technology and Research) grant to D. Xie.

\section{LITERATURE CITED}

Abe, H., Urao, T., Ito, T., Seki, M., Shinozaki, K., and YamaguchiShinozaki, K. 2003. Arabidopsis AtMYC2 (bHLH) and AtMYB2 (MYB) function as transcriptional activators in abscisic acid signaling. Plant Cell 15:63-78.

Anderson, J. P., Badruzsaufari, E., Schenk, P. M., Manners, J. M., Desmond, O. J., Ehlert, C., Maclean, D. J., Ebert, P. R., and Kazan, K. 2004. Antagonistic interaction between abscisic acid and jasmonate-ethylene signaling pathways modulates defense gene expression and disease resistance in Arabidopsis. Plant Cell 16:3460-3479.

Bechtold, N., Ellis, J., and Pelletier, G. 1993. In Planta Agrobacteriummediated gene transfer by infiltration of adult Arabidopsis thaliana plants. C. R. Acad. Sci. Paris 316:1194-1199.

Bell, E., and Mullet, J. E. 1991 Lipoxygenase gene-expression is modulated in plants by water deficit, wounding, and methyl jasmonate. Mol. Gen. Genet. 230:456-462.

Bell, E., Creelman, R. A., and Mullet, J. E. 1995. A chloroplast Lipoxygenase is required for wound-induced jasmonic acid accumulation in Arabidopsis. Proc. Natl. Acad. Sci. U.S.A. 92:8675-8679.

Benedetti, C. E., Xie, D. X., and Turner, J. G. 1995. AtCOI1-dependent expression of an Arabidopsis vegetative storage protein in flowers and siliques and in response to coronatine or methyl jasmonate. Plant Physiol. 109:567-572.

Bent, A. F. 2000. Arabidopsis in planta transformation: Uses, mechanisms, and prospects for transformation of other species. Plant Physiol. 124:1540-1547.

Berger, S., Bell, E., Sadka, A., and Mullet, J. E. 1995. Arabidopsis thaliana AtVSP is homologous to soybean Vspa and Vspb, genes encoding vegetative storage protein acid-phosphatases, and is regulated similarly by methyl jasmonate, wounding, sugars, light and phosphate. Plant Mol. Biol. 27:933-942.

Berger, S., Bell, E., and Mullet, J. E. 1996. Two methyl jasmonate-insensitive mutants show altered expression of AtVSP in response to methyl jasmonate and wounding. Plant Physiol. 111:525-531.

Bohland, C., Balkenhohl, T., Loers, G., Feussner, I., and Grambow, H. J. 1997. Differential induction of lipoxygenase isoforms in wheat upon treatment with rust fungus elicitor, chitin oligosaccharides, chitosan, and methyl jasmonate. Plant Physiol. 114:679-685.

Boter, M., Ruiz-Rivero, O., Abdeen, A., and Prat, S. 2004. Conserved MYC transcription factors play a key role in jasmonate signaling both in tomato and Arabidopsis. Genes Dev. 18:1577-1591.
Chen, W., Provart, N., J., Glazebrook, J., Katagiri, F., Chang, H., S. Eulgem, T., Mauch, F., Luan, S., Zou, G., Whitham, S. A., Budworth, P., R., Tao, Y., Xie, Z., Chen, X., Lam, S., Kreps, J. A., Harper, J. F., SiAmmour, A., Mauch-Mani, B., Heinlein, M., Kobayashi, K., Hohn, T., Dangl, J. L., Wang, X., and Zhu, T. 2002. Expression profile matrix of Arabidopsis transcription factor genes suggests their putative functions in response to environmental stresses. Plant Cell 14:559-574.

Cordero, M. J., Raventos, D., and San Segundo, B. 1994. Expression of a maize proteinase inhibitor gene is induced in response to wounding and fungal infection: Systemic wound-response of a monocot gene. Plant J. 6:141-150.

Creelman, R. A., and Mullet, J. E. 1997. Biosynthesis and action of jasmonates in plants. Annu. Rev. Plant Physiol. Plant Mol. Biol. 48:355-381.

Creelman, R. A., Tierney, M. L., and Mullet, J. E. 1992. Jasmonic acid methyl jasmonate accumulate in wounded soybean hypocotyls and modulate wound gene-expression. Proc. Natl. Acad. Sci. U.S.A. 89:4938-4941.

Dealy, M. J., Nguyen, K. V., Lo, J., Gstaiger, M., Krek, W., Elson, D., Arbeit, J., Kipreos, E. T., and Johnson, R. S. 1999. Loss of Cul1 results in early embryonic lethality and dysregulation of cyclin E. Nat. Genet. 23:245-248.

Deshaies, R. J. 1999. SCF and Cullin/Ring H2-based ubiquitin ligases. Annu. Rev. Cell Dev. Biol. 15:435-467.

Ellis, C., Karafyllidis, I., Wasternack, C., and Turner, J. G. 2002. The Arabidopsis mutant cev1 links cell wall signaling to jasmonate and ethylene responses. Plant Cell 14:1557-1566.

Engelberth, J., Schmelz, E. A., Alborn, H. T., Cardoza, Y. J., Huang, J., and Tumlinson, J. H. 2003. Simultaneous quantification of jasmonic acid and salicylic acid in plants by vapor-phase extraction and gas chromatography-chemical ionization-mass spectrometry. Anal. Biochem. 312:242-250

Entani, T., Iwano, M., Shiba, H., Che, F. S., Isogai, A., and Takayama, S. 2003. Comparative analysis of the self-incompatibility (S-) locus region of Prunus mume: Identification of a pollen-expressed F-box gene with allelic diversity. Genes Cells 8:203-213.

Feng, S., Ma, L., Wang, X., Xie, D., Dinesh-Kumar, S. P., Wei, N., and Deng, X. W. 2003. The COP9 signalosome interacts physically with $\mathrm{SCF}^{\mathrm{CO} 1}$ and modulates jasmonate responses. Plant Cell 15:10831094.

Feys, B. J. F., Benedetti, C. E., Penfold, C. N., and Turner, J. G. 1994. Arabidopsis mutants selected for resistance to the phytotoxin coronatine are male-sterile, insensitive to methyl jasmonate, and resistant to a bacterial pathogen. Plant Cell 6:751-759.

Gagne, J. M., Downes, B. P., Shiu, S. H., Durski, A. M., and Vierstra, R. D. 2002. The F-box subunit of the SCF E3 complex is encoded by a diverse superfamily of genes in Arabidopsis. Proc. Natl. Acad. Sci. U.S.A. 99:11519-11524.

Ha, S. B., Lee, B. C., Lee, D. E., Kuk, Y. I., Lee, A. Y., Han, O., and Back, K. 2002. Molecular characterization of the gene encoding rice allene oxide synthase and its expression. Biosci. Biotechnol. Biochem. 66:2719-2722.

Harms, K., Atzorn, R., Brash, A., Kuhn, H., Wasternack, C., Willmitzer, L., and Pena-Cortes, H. 1995. Expression of a flax allene oxide synthase cDNA leads to increased endogenous jasmonic acid (JA) levels in transgenic potato plants but not to a corresponding activation of JA-responding genes. Plant Cell 7:1645-1654.

He, P., Chintamanani, S., Chen, Z., Zhu, L., Kunkel, B., N., Alfana, J. R., Tang, X., and Zhou, J. M., 2004. Activation of a COI1-dependent pathway in Arabidopsis by Pseudomonas syringae type III effectors and coronatine. Plant J. 37:589-602.

Heitz, T., Bergey, D. R., and Ryan, C. A. 1997. A gene encoding a chloroplast-targeted lipoxygenase in tomato leaves is transiently induced by wounding, systemin, and methyl jasmonate. Plant Physiol. 114:10851093.

Hershko, A., and Ciechanover, A. 1998. The ubiquitin system. Annu. Rev. Biochem. 67:425-479.

Hilpert, B., Bohlmann, H., op den Camp, R. O., Przybyla, D., Miersch, O., Buchala, A., and Apel, K. 2001. Isolation and characterization of signal transduction mutants of Arabidopsis thaliana that constitutively activate the octadecanoid pathway and form necrotic microlesions. Plant J. 26:435-446.

Ingram, G. C., Doyle, S., Carpenter, R., Schultz, E. A., Simon, R., and Coen, E. S. 1997. Dual role for fimbriata in regulating floral homeotic genes and cell division in Antirrhinum. EMBO (Eur. Mol. Biol. Organ.) J. 16:6521-6534.

Ishiguro, S., Kawai-Oda, A., Ueda, J., Nishida, I., and Okada, K. 2001. The DEFECTIVE IN ANTHER DEHISCIENCE gene encodes a novel phospholipase A1 catalyzing the initial step of jasmonic acid biosynthesis, which synchronizes pollen maturation, anther dehiscence, and flower opening in Arabidopsis. Plant Cell 13:2191-2209. 
Ito, Y., Ozawa, A., Sawasaki, T., Endo, Y., Ochi, K., and Tozawa, Y. 2002. OsRALyase1, a putative F-box protein identified in rice, Oryza sativa, with enzyme activity identical to that of wheat RALyase. Biosci. Biotechnol. Biochem. 66:2727-2731.

Itoh, A., Schilmiller, A. L., Mccaig, B. C., and Howe, G. A. 2002. Identification of a jasmonate-regulated allene oxide synthase that metabolizes 9-hydroperoxides of linoleic and linolenic acids. J. Biol. Chem. 277:46051-46058.

Jensen, A. B., Raventos, D., and Mundy, J. 2002. Fusion genetic analysis of jasmonate-signaling mutants in Arabidopsis. Plant J. 29:595-606.

Jwa, N. S., Agrawal, G. K., Rakwal, R., Park, C. H., and Agrawal, V. P. 2001. Molecular cloning and characterization of a novel jasmonate inducible pathogenesis-related class 10 protein gene, JIOsPR10, from rice (Oryza sativa L.) seedling leaves. Biochem. Biophys. Res. Commun. 286:973-983.

Kubigsteltig, I., Laudert, D., and Weiler, E. W. 1999. Structure and regulation of the Arabidopsis thaliana allene oxide synthase gene. Planta 208:463-471.

Lai, Z., Ma, W., Han, B., Liang, L., Zhang, Y., Hong, G., and Xue, Y. 2002. An F-box gene linked to the self-incompatibility (S) locus of Antirrhinum is expressed specifically in pollen and tapetum. Plant Mol. Biol. 50:29-42.

Leclercq, J., Adams-Phillips, L. C., Zegzouti, H., Jones, B., Latche, A. Giovannoni, J. J., Pech, J. C., and Bouzayen, M. 2002. LeCTR1, a tomato CTR1-like gene, demonstrates ethylene signaling ability in Arabidopsis and novel expression patterns in tomato. Plant Physiol. 130:1132-1142.

Lee, G. I., and Howe, G. A. 2003. The tomato mutant sprl is defective in systemin perception and the production of a systemic wound signal for defense gene expression. Plant J. 33:567-576.

Li, L., Li, C., and Howe, G. A. 2001. Genetic analysis of wound signaling in tomato. Evidence for a dual role of jasmonic acid in defense and female fertility. Plant Physiol. 127:1414-1417.

Li, L., Li, C. Y., Lee, G. I., and Howe, G. A. 2002. Distinct roles for jasmonate synthesis and action in the systemic wound response of tomato. Proc. Natl. Acad. Sci. U.S.A. 99:6416-6421.

Li, L., Zhao, Y., McCaig, B. C., Wingerd, B. A., Wang, J., Whalon, M. E., Pichersky, E., and Howe, G. A. 2004. The tomato homolog of CORONATINE-INSENSITIVE1 is required for the maternal control of seed maturation, jasmonate-signaled defense responses, and glandular trichome development. Plant Cell 16:126-143.

Liechti, R., and Farmer, E. E. 2002. The jasmonate pathway. Science 296:1649-1650

Lorenzo, O., Chico, J. M., Sanchez-Serrano, J. J., and Solano, R. 2004 JASMONATE-INSENSITIVE1 encodes a MYC transcription factor essential to discriminate between different jasmonate-regulated defense responses in Arabidopsis. Plant Cell 16:1938-1950.

Ma, Q. H., and Wang, X. M. 2003. Characterization of an ethylene receptor homologue from wheat and its expression during leaf senescence. J. Exp. Bot. 54:1489-1490.

Mandaokar, A., Kumar, V. D., Amway, M., and Browse, J. 2003. Microarray and differential display identify genes involved in jasmonate-dependent anther development. Plant Mol. Biol. 52:775-786.

Manners, J. M., Penninckx, I. A. M. A., Vermaere, K., Kazan, K., Brown, R. L., Morgan, A., Maclean, D. J., Curtis, M. D., Cammue, B. P. A., and Broekaert, W. F. 1998. The promoter of the plant defensin gene PDF1.2 from Arabidopsis is systemically activated by fungal pathogens and responds to methyl jasmonate but not to salicylic acid. Plant Mol. Biol. 38:1071-1080.

Mason, H. S., and Mullet, J. E. 1990. Expression of two soybean vegetative storage protein genes during development and in response to water deficit, wounding, and jasmonic acid. Plant Cell 2:569-579.

Maucher, H., Stenzel, I., Miersch, O., Stein, N., Prasad, M., Zierold, U., Schweizer, P., Dorer, C., Hause, B., and Wasternack, C. 2004. The allene oxide cyclase of barley (Hordeum vulgare L.) -Cloning and organspecific expression. Phytochemistry 65:801-811

McConn, M., and Browse, J. 1996. The critical requirement for linolenic acid is pollen development, not photosynthesis, in an Arabidopsis mutant. Plant Cell 8:403-416.

McConn, M., Creelman, R. A., Bell, E., Mullet, J. E., and Browse, J. 1997. Jasmonate is essential for insect defense in Arabidopsis. Proc. Natl. Acad. Sci. U.S.A. 94:5473-5477.

McGinnis, K. M., Thomas, S. G., Soule, J. D., Strader, L. C., Zale, J. M., Sun, T. P., and Steber, C. M. 2003. The Arabidopsis SLEEPY1 gene encodes a putative F-box subunit of an SCF E3 ubiquitin ligase. Plant Cell 15:1120-1130.

Norman-Setterblad, C., Vidal, S., and Palva, E. T. 2000. Interacting signal pathways control defense gene expression in Arabidopsis in response to cell wall-degrading enzymes from Erwinia carotovora. Mol. PlantMicrobe Interact. 13:430-438.
Ogasawara, T., Sawasaki, T., Morishita, R., Ozawa, A., Madin, K., and Endo, Y. 1999. A new class of enzyme acting on damaged ribosomes: Ribosomal RNA apurinic site specific lyase found in wheat germ. EMBO (Eur. Mol. Biol. Organ.) J. 18:6522-6531.

Penninckx, I. A. M. A., Thomma, B. P. H. J., Buchala, A., Metraux, J. P., and Broekaert, W. F. 1998. Concomitant activation of jasmonate and ethylene response pathways is required for induction of a plant defensin gene in Arabidopsis. Plant Cell 10:2103-2113.

Penninckx, I. A. M. A., Eggermont, K., Schenk, P. M., Ackerveken, G. V. D., Cammue, B. P. A., and Thomma, B. P. H. J. 2003. The Arabidopsis mutant iop1 exhibits induced over-expression of the plant defensin gene PDF1.2 and enhanced pathogen resistance. Mol. Plant Pathol. 4:479-486.

Petersen, M., Brodersen, P., Naested, H., Andreasson, E., Lindhart, U., Johansen, B., Nielsen, H. B., Lacy, M., Austin, M. J., Parker, J. E., Sharma, S., B., Klessig., D. F., Martienssen, R., Mattsson, O., Jensen, A. B., and Mundy, J. 2000. Arabidopsis MAP kinase 4 negatively regulates systemic acquired resistance. Cell 103:1111-1120.

Rakwal, R., and Komatsu, S. 2000. Role of jasmonate in the rice (Oryza sativa $L$.) self-defense mechanism using proteome analysis. Electrophoresis 21:2492-2500.

Rakwal, R., Kumar, A. G., and Jwa, N. S. 2001. Characterization of a rice (Oryza sativa L.) Bowman-Birk proteinase inhibitor: Tightly light regulated induction in response to cut, jasmonic acid, ethylene and protein phosphatase 2A inhibitors. Gene 263:189-198.

Reinbothe, S., Reinbothe, C., and Parthier, B. 1993. Methyl jasmonateregulated translation of nuclear-encoded chloroplast proteins in barley (Hordeum-Vulgare l Cv Salome). J. Biol. Chem. 268:1060610611.

Ren, C., Pan, J., Peng, W., Genschik, P., Hobbie, L., Hellmann, H., Estelle, M., Gao, B., Peng, J., Sun, C., and Xie, D. 2005. Point mutations in Arabidopsis Cullin1 reveal its essential role in jasmonate response. Plant J. 42:514-24.

Reymond, P., and Farmer, E. E. 1998. Jasmonate and salicylate as global signals for defense gene expression. Curr. Opin. Plant Biol. 1:404-411.

Riemann, M., Muller, A., Korte, A., Furuya, M., Weiler, E. W., and Nick, P. 2003. impaired induction of the jasmonate pathway in the rice mutant hebiba. Plant Physiol. 133:1820-1830.

Royo, J., Leon, J., Vancanneyt, G., Albar, J. P., Rosahl, S., Ortego, F., Castanera, P., and Sanchez-Serrano, J. J. 1999. Antisense-mediated depletion of a potato lipoxygenase reduces wound induction of proteinase inhibitors and increases weight gain of insect pests. Proc. Natl. Acad Sci. U.S.A. 96:1146-1151.

Samach, A., Klenz, J. E., Kohalmi, S. E., Risseeuw, E., Haughn, G. W., and Crosby, W. L. 1999. The UNUSUAL FLORAL ORGANS gene of Arabidopsis thaliana is an F-box protein required for normal patterning and growth in the floral meristem. Plant J. 20:433-445.

Sanders, P. M., Lee, P. Y., Biesgen, C., Boone, J. D., Beals, T. P., Weiler, E. W., and Goldberg, R. B. 2000. The Arabidopsis DELAYED DEHISCENCE1 gene encodes an enzyme in the jasmonic acid synthesis pathway. Plant Cell 12:1041-1061.

Santamaria, M., Thomson, C. J., Read, N. D., and Loake, G. J. 2001. The promoter of a basic PR1-like gene, AtPRB1, from Arabidopsis establishes an organ-specific expression pattern and responsiveness to ethylene and methyl jasmonate. Plant Mol. Biol. 47:641-652.

Sasaki, A., Itoh, H., Gomi, K., Ueguchi-Tanaka, M., Ishiyama, K., Kobayashi, M., Jeong, D. H., An, G., Kitano, H., Ashikari, M., and Matsuoka, M. 2003. Accumulation of phosphorylated repressor for gibberellin signaling in an F-box mutant. Science 299:1896-1898.

Schmelz, E. A., Alborn, H. T., Banchio, E., and Tumlinson, J. H. 2003. Quantitative relationships between induced jasmonic acid levels and volatile emission in Zea mays during Spodoptera exigua herbivory. Planta 216:665-673.

Seo, H. S., Song, J. T., Cheong, J. J., Lee, Y. H., Lee Y. W., Hwang, I., Lee, J. S., and Choi, Y. D. 2001. Jasmonic acid carboxyl methyltransferase: A key enzyme for jasmonate-regulated plant responses. Proc. Natl Acad. Sci. U.S.A. 98:4788-4793.

Seto, H., Fujioka, S., Fujisawa, H., Goto, K., Nojiri, H., Yamane, H., and Yoshida, S. 1996. Preparation of (+/-)-2-(2,3-H-2(2))jasmonic acid and its methyl ester, methyl (+/-)-2-(2,3-H-2(2))jasmonate. Biosci. Biotechnol. Biochem. 60:1709-1711.

Shen, W. H., Parmentier, Y., Hellmann, H., Lechner, E., Dong, A., Masson, J., Granier, F., Lepiniec, L., Estelle, M., and Genschik, P. 2002. Null mutation of AtCUL1 causes arrest in early embryogenesis in Arabidopsis. Mol. Biol. Cell 13:1916-1928.

Simon, R., Carpenter, R., Doyle, S., and Coen, E. 1994. Fimbriata controls flower development by mediating between meristem and organ identity genes. Cell 78:99-107.

Sivasankar, S., Sheldrick, B., and Rothstein, S. J. 2000. Expression of allene oxide synthase determines defense gene activation in tomato. Plant Physiol. 122:1335-1342. 
Staswick, P. E. 1992. Jasmonate, genes, and fragrant signals. Plant Physiol. 99:804-807.

Staswick, P. E., Yuen, G. Y., and Lehman, C. C. 1998. Jasmonate signaling mutants of Arabidopsis are susceptible to the soil fungus Pythium irregulare. Plant J. 15:747-754.

Staswick, P. E., Tiryaki, I., and Rowe, M. L. 2002. Jasmonate response locus JARl and several related Arabidopsis genes encode enzymes of the firefly luciferase superfamily that show activity on jasmonic, salicylic, and indole-3-acetic acids in an assay for adenylation. Plant Cell 14:1405-1415.

Stenzel, I., Hause, B., Maucher, H., Pitzschke, A., Miersch, O., Ziegler, J., Ryan, C. A., and Wasternack, C. 2003a. Allene oxide cyclase dependence of the wound response and vascular bundle-specific generation of jasmonates in tomato-Amplification in wound signaling. Plant $\mathrm{J}$. 33:577-589.

Stenzel, I., Hause, B., Miersch, O., Kurz, T., Maucher, H., Weichert, H., Ziegler, J., Feussner, I., and Wasternack, C. 2003b. Jasmonate biosynthesis and the allene oxide cyclase family of Arabidopsis thaliana. Plant Mol. Biol. 51:895-911.

Stintzi, A., and Browse, J. 2000. The Arabidopsis male-sterile mutant, opr3, lacks the 12-oxophytodienoic acid reductase required for jasmonate synthesis. Proc. Natl. Acad. Sci. U.S.A. 97:10625-10630.

Stintzi, A., Weber, H., Reymond, P., Browse, J., and Farmer, E. E. 2001. Plant defense in the absence of jasmonic acid: The role of cyclopentenones. Proc. Natl. Acad. Sci. U.S.A. 98:12837-12842.

Taylor, S., Hofer, J., and Murfet, I. 2001. Stamina pistilloida, the Pea ortholog of Fim and $U F O$, is required for normal development of flowers, inflorescences, and leaves. Plant Cell 13:31-46.

Thomma, B. P. H. J., Eggermont, K., Penninckx, I. A. M. A., Mauch-Mani, B., Vogelsang, R., Cammue, B. P. A., and Broekaert, W. F. 1998. Separate jasmonate-dependent and salicylate-dependent defense response pathways in Arabidopsis are essential for resistance to distinct microbial pathogens. Proc. Natl. Acad. Sci. U.S.A. 95:15107-15111.

Ushijima, K., Sassa, H., Dandekar, A. M., Gradziel, T. M., Tao, R., and Hirano, H. 2003. Structural and transcriptional analysis of the self-incompatibility locus of almond: Identification of a pollen-expressed F-box gene with haplotype-specific polymorphism. Plant Cell 15:771-781.
Vignutelli, A., Wasternack, C., Apel, K., and Bohlmann, H. 1998. Systemic and local induction of an Arabidopsis thionin gene by wounding and pathogens. Plant J. 14:285-295.

Vijayan, P., Shockey, J., Levesque, C. A., Cook, R. J., and Browse, J. 1998. A role for jasmonate in pathogen defense of Arabidopsis. Proc. Natl. Acad. Sci. U.S.A. 95:7209-7214.

Voros, K., Feussner, I., Kuhn, H., Lee, J., Graner, A., Lobler, M., Parthier, B., and Wasternack, C. 1998. Characterization of a methyljasmonateinducible lipoxygenase from barley (Hordeum vulgare $c v$. Salome) leaves. Eur. J. Biochem. 251:36-44.

Wang, Y., Penfold, S., Tang, X., Hattori, N., Riley, P., Harper, J. W., Cross, J. C., and Tyers, M. 1999. Deletion of the Cull gene in mice causes arrest in early embryogenesis and accumulation of cyclin E. Curr. Biol. 9:1191-1194.

Wasternack, C., and Parthier, B. 1997. Jasmonate signaled plant gene expression. Trends Plant Sci. 2:302-307.

Weber, H., Vick, B. A., and Farmer, E. E. 1997. Dinor-oxo-phytodienoic acid: A new hexadecanoid signal in the jasmonate family. Proc. Natl. Acad. Sci. U.S.A. 94:10473-10478.

Xie, D., Feys, B. F., James, S., Nieto-Rostro, M., and Turner, J. G. 1998. COI1: An Arabidopsis gene required for jasmonate-regulated defense and fertility. Science 280:1091-1094.

Xu, L., Liu, F., Wang, Z., Peng, W., Huang, R., Huang, D., and Xie, D. 2001. An Arabidopsis mutant cexl exhibits constant accumulation of jasmonate-regulated AtVSP, Thi2.1 and PDF1.2. FEBS (Fed. Eur. Biochem. Soc.) Lett. 494:161-164.

Xu, L., Liu, F., Lechner, E., Genschik, P., Crosby, W. L., Ma, H., Peng, W., Huang, D., and Xie, D. 2002. The SCF ${ }^{\mathrm{COI} 1}$ ubiquitin-ligase complexes are required for jasmonate response in Arabidopsis. Plant Cell 14:1919-1935.

Yamane, H., Ikeda, K., Ushijima, K., Sassa, H., and Tao, R. 2003. A pollen-expressed gene for a novel protein with an F-box motif that is very tightly linked to a gene for S-RNase in two species of cherry, Prunus cerasus and $P$. avium. Plant Cell Physiol. 44:764-769.

Zhang, S., Sandal, N., Polowick, P. L., Stiller, J., Stougaard, J., and Fobert, P. R. 2003. Proliferating Floral Organs (Pfo), a Lotus japonicus gene required for specifying floral meristem determinacy and organ identity, encodes an F-box protein. Plant J. 33:607-619. 